\title{
Analysis of Terrorism Criminal Act Case Handling In Indonesia
}

\author{
Netty Rosdiana Siagian ${ }^{1}$ \\ \{dianaharleybm@gmail.com\} \\ ${ }^{1}$ Department of Law, Universitas Jayabaya, Indonesia
}

\begin{abstract}
Terrorism funding criminal act case handling is an important effort in terrorism criminal act eradication. Currently the efforts only focus on terrorism criminal actor handling but they don't pay attention to funding from the terrorism criminal actors. The study used was normative juridical study. Normative legal study is literature study namely the study of legal books related to the analysis used in the study, which was qualitative analysis. The result of the study shows that criminal terrorism act handling was a legal consequence and a form of accountability that had to be upheld because criminal terrorism act was an extraordinary and certainly harmful crime so terrorism criminal act handling had to be done optimally in accordance with legal procedures. The obstacle faced in terrorism criminal act handling was the inconsistency of formulation of the criminal system on terrorism criminal act so legal renewal was required through improvement of criminal act formulation.
\end{abstract}

Keywords: Handling; Criminal Act; Terrorism.

\section{Introduction}

Terrorism is one of the crimes that has become a highlight of all countries around the world that are considered disturbing and frightening. Acts of terror cause a loss of security in the midst of society and reduce the authority of the government as a body that should provide protection and security [1]. Terrorism is a crime against humanity in an organized movement. Nowadays, terrorism has a broad and global network that threatens national and international peace and security.

In Indonesia, the Law No. 9/2013 on the Prevention and Eradication of Criminal Acts of Terrorism Funding, Article 1 paragraph 2 states "Terrorism Crimes are all acts that meet the elements of criminal offenses in accordance with the provisions in the Law governing the eradication of terrorist acts [2]." The government issued this law because of the critical conditions in Indonesia, i.e. terror attacks continue to occur.

Efforts to eradicate terrorism by the government are considered by various groups to still reap the pros and cons because the government's efforts so far have been limited to efforts to arrest and punish perpetrators but do not pay attention to other aspects, for example terrorism funding. Therefore, it is believed that efforts to tackle terrorism will not be optimal without the prevention and eradication of terrorism funding [3].

So far, the government has tried to tackle terrorism by enacting the Law No. 15/2003 on the Establishment of Government Regulations in lieu of the Law No. 1/2002 on the Eradication of Terrorism Criminal Acts into the Law No. 8/2010 on Money Laundering. Related to free and active foreign policy, the Government of the Republic of Indonesia has enacted the Law No. 37/1999 on 
Foreign Relations, the Law No. 24/2000 on International Treaties, and the Law No. 9/2013 on the Prevention and Eradication of Criminal Acts on Terrorism Funding. The issuance of the aforementioned laws and regulations is directed to answer the people's anxiety over acts of terror that occur.

In principle, the law of ratification of a convention has not yet been fully implemented or requires further regulation so that the terrorism can be handled. Muladi states that terrorism is an extraordinary crime that requires treatment by utilizing extraordinary ways for some reasons. First, terrorism is an act that creates the greatest danger against human rights. Second, terrorism targets are random or indiscriminate which tend to sacrifice innocent people. Third, there is possibility of using weapons of mass destruction by utilizing modern technology. Fourth, it tends to be negative synergy between national and international terrorist organizations. Fifth, there is possibility of cooperation between terrorist organizations and organized crime both national and transnational which can jeopardize international peace and security [4].

In Indonesian law, there is Nullum crimen sine poena, which means that no crime should be allowed to pass without punishment. However, due to the fact that terrorism is no longer just an international crime and has become an international organized crime, it is very difficult to eradicate terrorism without cooperation in strict legal regulations. Therefore, terrorism offense can be properly addressed and cannot develop amidst the social life of the community [5].

Terrorism is a very troubling crime and has caused many casualties. Therefore, funding problems are the main element in every act of terrorism so that efforts to tackle terrorism crime are believed to be not as successful as expected without eradicating their funding. Efforts to eradicate terrorism carried out by the government do not seem to be maximal, and thus it needs special handling, especially in terms of funding.

Indonesia is one of the countries that often experience terrorism crimes, so the chain of terrorism offenses must be based on law in its application. It is expected that terrorist activities will not be able to proceed as they should and there will not be more acts of terror in the Republic of Indonesia in the future.

Therefore, the Government of the Republic of Indonesia made various efforts to refine and renew efforts to prevent and eradicate terrorism. Therefore, the author is interested in explaining this issue in a scientific study entitled "Analysis of Terrorism Criminal Act Case Handling Referring to the Law No. 9/2013."

\section{Research Methods}

The method used in this research is Normative Juridical Approach. Normative legal research is a research with a statutory, conceptual, analytical, comparative, historical, philosophical approach, and case approach. By conducting library research, initial data were obtained to be analyzed and used as material in this paper. The sources of legal material consist of secondary data and primary data [6]. The data analysis used in this study is qualitative analysis.

\section{Result and Discussion}

\subsection{Terrorism Criminal Case Handling Referring to the Law No. 9/2013.}

The Law No. 9/2013 confirms that terrorism funding is any act in the context of providing, collecting, giving, or lending Funds, both directly and indirectly, with the intention to be used and/or known to be used to carry out terrorist activities, terrorist organizations, or terrorist [7]. 
Terrorism in Indonesia is included in the criminal sanctions section. Criminal sanctions are the imposition of suffering on a person found guilty of committing a crime or a criminal act through a series of judicial proceedings by a specific authority or law. With the imposition of criminal sanctions, it is expected that people will not commit criminal acts again. Criminal sanctions contain elements and characteristics as follows: first, the criminal is in essence an imposition of suffering or misery or other unpleasant effects. Second, the criminal is intentionally given by persons or entities that have the authority. Third, the crime is imposed on someone who has committed a crime according to the law. Fourth, the crime is a statement of self-deprecation by the state of a person for violating the law [8].

The purpose of criminal law is to fulfill a sense of justice for all levels of society. Criminal law also has control of a criminal act since, in criminal law, someone who commits a crime will be educated and sanctioned in accordance with the criminal act he has done. Therefore, someone who commits the crime can feel the deterrent effect so as not to repeat his actions again after undergoing the sanction. The current problem is the spread of terrorism cases, although it has been through several criminal efforts, but it is still not optimal.

Hikmahanto Juwana, an International Law expert from Universitas Indonesia, recognizes the difficulty of making restrictions on terrorism even though it can be felt factually and can be seen its characteristics, such as attacks with violence that are indiscriminate (blindly, carelessly), carried out in civil places or against people civilian [9].

Thus, the Law No. 9/2013 is considered an appropriate statutory regulation to break the terrorism funding link and must certainly be supported by law enforcement to be carried out properly and can also be justified legally. The element of funding is one of the main factors in every terrorist act. Thus, the efforts to tackle terrorism must be followed by efforts to prevent and eradicate funding. The Law No. 9/2013 on Terror Funding Criminal Acts is a regulation established by the Government of Indonesia in responding to acts of terrorism which focuses on preventing and eradicating acts of terrorism funding.

Article 2 of the Law No. 9/2013 on funding is applicable to:

a. Any person who commits or intends to commit a criminal act of financing terrorism in the territory of the Unitary Republic of Indonesia and outside the territory of the Unitary State of the Republic of Indonesia; and/or

b. Funds related to terrorism funding in the territory of the Unitary Republic of Indonesia and outside the territory of the Unitary Republic of Indonesia.

In addition, this law also applies to criminal acts of financing terrorism that occur outside the territory of the Unitary Republic of Indonesia if:

a. conducted by Indonesian citizens;

b. related to the Criminal Acts of Terrorism against Indonesian citizens;

c. related to the terrorism act against Indonesian government facilities, including representatives of Indonesia or the residence of diplomatic or consular officials from Indonesia;

d. related to the terrorism act carried out as an effort to force the Indonesian government to take or not take an action;

e. related to the terrorism act against aircraft operated by the Indonesian state;

f. related to the terrorism act on a ship having the flag of the Unitary State of the Republic of Indonesia or an aircraft registered under Indonesian law at the time the crime was committed; or

g. carried out by every person who does not have citizenship and resides in the territory of the Unitary Republic of Indonesia.

Article 4 states that any person who intentionally provides, collects, gives, or lends funds, directly or indirectly, with the intention of being used wholly or in part to commit terrorism acts, terrorist organizations, or terrorists is convicted of a criminal offense financing terrorism with imprisonment a maximum of 15 (fifteen) years and a criminal fine of no more than Rp1,000,000,000.00 (one billion rupiah). Article 5 states that any person who commits an evil agreement, trial, or co-administration to 
commit a crime of financing terrorism shall be convicted of committing a crime of financing terrorism with the same crime as referred to in Article 4.

Article 6 states that any person who intentionally plans, organizes or moves others to commit criminal acts as referred to in Article 4 shall be convicted of committing a criminal act of financing terrorism with life imprisonment or imprisonment for a maximum term of 20 (twenty) years. Article 7 states that in the event that the convicted person is unable to pay the criminal penalties as referred to in Article 4 and Article 5, the criminal penalties will be replaced with a maximum imprisonment of 1 (one) year 4 (four) months.

Handling of terrorism is a legal consequence and the form of responsibility that must be upheld because terrorism is an extraordinary crime and clearly very detrimental so that handling of terrorism crime must be carried out optimally in accordance with legal procedures. Thus, one of the ways to be able to encourage the prevention and eradication of terrorism in Indonesia is breaking the chain of terrorism violence. However, to do so, it is certainly not enough to use repressive measures alone, but there are also preventive measures in them. This will prevent or cut off terrorism networks themselves. One of them is to cut off or stop the flow of terrorist funds in order to maintain public order and security.

\subsection{Terrorism Criminal Case Handling Referring to the Law No.9/2013.}

The funding aspect is an important chain behind an act of terrorism. Terrorism activities require funds in a variety of needs such as recruitment, propaganda, training, logistical supplies, purchasing weapons and other supporting equipment as well as accommodation for execution. In general, the understanding of the element of funding is one of the main factors in every act of terrorism. Thus, the efforts to tackle terrorism should be followed by efforts to eradicate terrorism funding.

The criminal liability of the perpetrators in the law regarding the criminal act of financing terrorism is more focused on the imposition of serious crimes, especially against sponsors of funds such as corporations and corporate controlling personnel. It is also due to the possibility of criminal fines in lieu of fines from the sale of assets or assets of the corporation after the corporation or corporate control personnel do not pay or underpaid fines in the criminal decision [10].

Soerjono Soekanto [11] states that law enforcement is not merely the implementation of legislation, there are other factors that influence it, namely: First, the legal factor itself. Second, law enforcement factors, i.e. the parties who form or apply the law. Third, the factor of facilities that support law enforcement. Fourth, community factors, i.e. environmental factors where the law applies or is applied. Fifth, cultural factors, i.e. as the work, creation, and taste based on human initiative in the struggle of life.

Terrorism act is any act that fulfills an element of criminal offense in accordance with the provisions in the law concerning criminal acts of financing terrorism. One of the facts that based the issuance of the Law No. 9/2013 on the Criminal Acts of Terrorist Funding, is that the element of funding is one of the main factors in every terrorist act, so efforts to tackle terrorism must be followed by efforts to prevent and eradicate terrorism funding. However, in reality, law enforcement in terrorism often experiences obstacles such as:

a. Statutory Factors (Legal substance). In tackling terrorism, inconsistencies in the formulation of the criminal system against terrorism often occur so that legal reform is needed through the improvement of the formulation of criminal acts.

b. Law Enforcement Factors In short, it can be said that this structural component allows us to expect how a legal system should work. Law enforcers are key in upholding terrorism, however, there are usually many conflicts in the social life of the community. 
c. Facility Factors In the law enforcement of terrorism, facilities and infrastructure are deemed incomplete in terms of providing networks to detect perpetrators of funding to stop terrorism crimes.

d. Every citizen or group of people must have legal awareness, which is high, medium or low legal compliance. This means that terrorism cases often face the pros and cons in society so that the impact on the slow resolution of terrorism cases on the one hand, upholding the law while on the other hand it is considered a violation of human rights.

e. Cultural Factors Many cultural variations can lead to certain perceptions of law enforcement. Cultural variations are very difficult to be uniform, therefore law enforcement of terrorism should pay attention to aspects of culture that grow in the social life of the community.

Thus, the problem of law enforcement is an issue that is never ceased to be discussed. In this case, the law is no more than ideas or concepts that reflect in it what is called justice, order and legal certainty as outlined in the form of legislation aiming to achieve certain goals. However, it does not mean that the applicable legal regulations are interpreted to be complete and perfect, but rather a framework that still needs improvement. To realize the purpose of the law, the level of professionalism of the law enforcers is highly determined, which includes the ability and skills both in spelling out regulations and in applying them.

\section{Conclusion}

Handling of terrorism is a legal consequence and the form of responsibility that must be upheld because terrorism is an extraordinary crime and clearly very detrimental so that handling of terrorism crime must be carried out optimally in accordance with legal procedures. The barriers faced in handling the terrorism funding include inconsistencies in the formulation of the criminal system against criminal acts of terrorism. Thus, legal reform is needed through improving the formulation of criminal acts in its enforcement usually experiencing many conflicts in the social life of the community. Besides, the facilities and infrastructure are considered to be incomplete in terms of providing networks to detect perpetrators of funding in order to stop terrorism and cultural variations that can lead to certain perceptions of law enforcement. Cultural variations are very difficult to be uniform. Thus, law enforcement of terrorism should pay attention to aspects of culture that grow in the social life of society which often face the pros and cons in society. As a result, the impact on the slow resolution of terrorism cases on the one hand, upholding the law while on the other hand it is considered a violation of human rights.

\section{Acknowledgments}

The Author wishes to thank the Head of Semarang State University and Head of Faculty of Law for providing a facility to join International Conference in ICILS $3^{\text {rd }}$ International Conference 2020.

\section{References}

[1] Sukawarsini Jelantik, Terorisme: Tinjau Psiko-Politis, Peran Media Kemiskinan dan Kemanan Nasional, Yayasan Pustaka Obor Indonesia, Jakarta, 2010.

[2] Article 1 Paragraph 2, Law No. 9/2013 on Prevention and Eradication of Terrorism Funding Criminal Acts.

[3] Sulistyo, Hermawan, Beyond Terrorism, Pustaka Sinar Harapan, Jakarta, 2002, p. 33

[4] Muladi, "Penanggulangan Terorisme Sebagai Tindak Pidana Khusus", Material for Safeguarding Terrorism as a Special Criminal Act, Jakarta, January 28, 2004. 
[5] However, in law enforcement to thoroughly investigate the problem of financing terrorism, it is still experiencing difficulties. Abdul Wahid, Kejahatan Terorisme Perspektif Agama, HAM dan Hukum, PT Refika Aditama, Bandung, 2011, p. 22.

[6] Jinny Ibrahim, Teori Metodlogi Penelitian Hukum Normatif, Bayumedia Publishing, Surabaya, 2005, p. 300.

[7] Terrorism has actually become a scourge for Indonesian people. The series of bombing incidents that occurred in the territory of the Unitary Republic of Indonesia have caused widespread fear in the community, resulting in loss of life and property loss, thus causing an unfavorable influence on Indonesia's social, economic, political life and relations with the international world. Lukman Hakim in his book "Terrorisme di Indonesia" states that "Talking about the problem of terrorism, it is almost always associated with radical religious groups." Article 1 Paragraph 1, Law No. 9/2013 on Prevention and Eradication of Terrorism Funding Criminal Acts.

[8] Mahrus Ali, Dasar-Dasar Hukum Pidana, Sinar Grafika, Jakarta, 2015. 37

[9] Todung Mulya Lubis, Masyarakat Sipil dan Kebijakan Negara Kasus perpu/RUU Tindak Pidana Terorisme, dalam Mengenang Perppu Antiterorisme, Suara Muhammadiyah, Jakarta, 2003, p. 173

[10] RO Siahaan, Tindak Pidana Khusus, R.A.O. Press, Cibubur, 2009. Pg. 201

[11] Soerjono Soekanto, Faktor-Faktor Yang Mempengaruhi Penegakan Hukum, Rajawali, Jakarta, 1983, p. 5. 